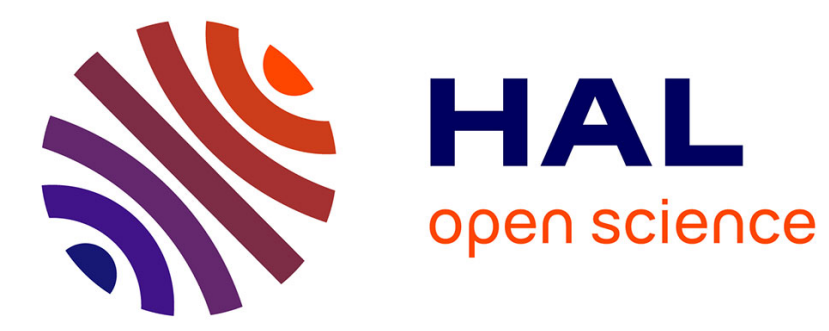

\title{
Organic signatures of fireplaces: Experimental references for archaeological interpretations
}

\author{
Mathieu Lejay, Marie Alexis, Katell Quénéa, Farid Sellami, François Bon
}

\section{To cite this version:}

Mathieu Lejay, Marie Alexis, Katell Quénéa, Farid Sellami, François Bon. Organic signatures of fireplaces: Experimental references for archaeological interpretations. Organic Geochemistry, 2016, 99, pp.67-77. 10.1016/j.orggeochem.2016.06.002 . hal-01360334

\section{HAL Id: hal-01360334 https://hal.sorbonne-universite.fr/hal-01360334}

Submitted on 6 Sep 2016

HAL is a multi-disciplinary open access archive for the deposit and dissemination of scientific research documents, whether they are published or not. The documents may come from teaching and research institutions in France or abroad, or from public or private research centers.
L'archive ouverte pluridisciplinaire HAL, est destinée au dépôt et à la diffusion de documents scientifiques de niveau recherche, publiés ou non, émanant des établissements d'enseignement et de recherche français ou étrangers, des laboratoires publics ou privés. 
1 Organic signatures of fireplaces: experimental references

2 for archaeological interpretations

3 Mathieu Lejay a, Marie Alexis ${ }^{b^{*}}$, Katell Quénéa ${ }^{\text {b }}$, Farid Sellami a,c, François

4 Bon $^{\text {a }}$

5 a Laboratoire TRACES, UMR 5608 CNRS, Université Toulouse Jean Jaurès,

631058 Toulouse cedex 9, France

7 b Laboratoire METIS, UMR 7619 CNRS, Université Pierre et Marie Curie, 875252 Paris cedex 5, France

9 c INRAP GSO, Centre archéologique du Château de Campagne, 24260

10 Campagne, France

11 * Corresponding author at

12 Laboratoire METIS, UMR 7619 CNRS, Université Pierre et Marie Curie, 13 Site Jussieu, Case 120, Tour 56-66, 4e étage, 75252 Paris cedex 5, France

14 Tel. +33 (0)1.44.27.50.27;

15 fax. $+33(0) 1.44 .27 .41 .64$.

$16 \quad$ E mail address: marie.alexis@upmc.fr (M. Alexis)

18 ABSTRACT

19 The use of fire is a well-established human practice, at least from the Late 20 Pleistocene. The variability in fuel type highlights complex practices 21 regarding fire technology throughout this period. This contribution provides 22 the organic signatures from fireplaces and is based on a set of experimental 23 studies using different types of fuel, notably bone and/or wood. Soil layers 24 affected by fire operation were compared with soils unaffected by heating 25 and soils impregnated with unburned bone fat. The carbon content, and 26 lipid and bulk organic matter (OM) composition were determined through 
27 organic carbon measurement, gas chromatography-mass spectrometry (GC-

28 MS), as well as TMAH-assisted pyrolysis coupled to GC-MS.

29 With the exception of the wood-fueled fireplace, an increase in organic 30 carbon content was caused by fireplace operation. The products of 31 triacylglycerol degradation (diacids, oxo-acids, and glycerol derivatives)

32 reflected the contribution from animal fat affected by the oxidation process 33 with or without thermal alteration. The branched unsaturated $\mathrm{C}_{9: 0}$ and $\mathrm{C}_{10: 0}$ 34 acids were detected only in py(TMAH)-GC-MS of soil impregnated with bone 35 fat that was not thermally altered. The branched diacids, ketones, lactones 36 detected in lipid extract, and short chain acids and $n$-alkane/n-alkene 37 doublets detected in py(TMAH-GC-MS), were produced by thermal 38 alteration of animal fat. Finally, in the fireplace fueled with wood only, 39 phenolic compounds, benzoic acids and benzene derivatives were detected 40 and reflected the contribution of charred and uncharred plant OM.

41 The results from lipid and bulk OM characterization permitted to advance 42 the organic signatures obtained as an experimental reference dataset specifically for the identification of fuel type used in fireplaces.

\section{Highlights}

Bone fires lead to a significant increase in soil OC content, whereas no variation was noticed for wood fire

Soil lipid and bulk OM distributions reflected the type of fuel used for experimental fires

50 Characterization of soil lipids and bulk OM permitted identification of 51 byproducts of thermal alteration

52 Organic signatures from experimental fireplaces provide a reference for 53 archaeological applications. 
56 Fireplace, Prehistory, Experimental References, Organic signature, Soil 


\section{Introduction}

58 The use of fire by hominins is a classic field of study within the prehistoric 59 discipline history and has provided a suite of publications, debates, and controversies since the $19^{\text {th }}$ century (see Roebroeks and Villa, 2011 and

61 Sandgathe et al., 2011 for recent examples). Dating the earliest fire use has been

62 a key question since the beginning of the discipline. Moreover, during the last few

63 decades an increase in interest regarding the study of fire related remains has 64 been observed, likely due to the fact that these remains represent both

65 technologically and sociologically significant shifts. The pyrotechnology of ancient societies is most often investigated through several approaches, including anthracology (Théry-Parisot, 2001), ash studies (Canti, 2003), taphonomy (ThéryParisot et al., 2010), ethnography (Henry and Théry-Parisot, 2014), magnetic susceptibility (Bellomo, 1993), and micromorphology (Mentzer, 2012 and references therein).

These studies have significantly improved our understanding of fireplace operation (e.g. type of fuel, re-use and structure management) and proposed several ethnographically-based models of utilization (e.g. specialized vs. multipurpose, expedient vs. curated). However, direct interpretation of archaeological vestiges remains difficult (Coudret et al., 1989) as archaeological data are rarely explicit. The necessity for an experimental dataset, based on the production and utilization of experimental fireplaces, thus seems apparent if we wish to construct an interpretative tool for the deciphering of the archaeological data.

Experimental investigations of prehistoric pyrotechnology are a well-established trend in archaeological science; the production of reference databases is regularly used to tackle taphonomic and functional questions (March et al., 2014; Mallol et al., 2013 and references therein). Unfortunately, the numerous parameters inherent in fireplace operation (e.g. type, state and quantity of fuel, type and state of underlying sediment, operator intervention or not, extinction, re-use) combined with the attempt to reconstruct different types of use (e.g. fireplace morphology and layout, different cooking methods, different types of cooked 
products) result in complex experimental data, within which it is often difficult to isolate and characterize individual aspects (Aldeias et al. 2016). More specifically these attempts to obtain reference collections rarely took into account the thermal alteration of the organic matter $(\mathrm{OM})$ in archaeological contexts. Ultimately, databases from early experiments were rarely completely published and this lack of documentation hampers our ability to move forward. We are thus faced with the necessary task of systematizing, documenting, and publishing these experimental approaches.

Regarding the investigation of OM in archaeological remains through chemical methods, the exploration of prehistoric fireplaces is less advanced than other domains of archaeological chemistry, the analysis of residues in pottery for example (Evershed et al., 2001; Barnard and Eerkens, 2007; Evershed, 2008; Steele, 2013; Reber et al., 2015). In these studies, the main objectives were to recognize the content and use of the containers, despite the numerous processes that might confound interpretation of the chemical data, such as complex ancient practices, taphonomic modifications, or methodological issues (e.g. Reber and Evershed, 2004; Barnard et al., 2007). Even though they provide methodological and interpretative guidelines, results obtained from pottery analysis cannot be directly transferred to fireplace studies due to the differences that are expected in the archaeological context and then in the processes of organic residue formation and preservation.

Concerning fireplace investigations, pioneering studies identified lipids in cave fireplaces, using gas chromatography (GC) and thin-layer chromatography (Rottländer, 1989). The latter recognized the presence of reindeer fat and horse fat via comparison with actual reference sets, but he could not determine if their presence was related to fireplace operation (e.g. fuel type) or their utilization (e.g. cooking, animal carcass processing). With the spread of GC-mass spectrometry (GC-MS) in the 1990s, studies in all aspects of archaeological chemistry multiplied (Regert, 2011) and the study of fireplaces became more frequent (e.g. March et al. 1989; March, 1995 ; Buonasera, 2005; Lucquin, 2007; Kedrowski et al., 2009). More recent researches in the field also involved isotopic investigation 
119 including bulk (e.g. Heron et al., 2010) and compound specific $\delta^{13} \mathrm{C}$ analysis (e.g.

120 March, 2013; Buonasera et al., 2015).

121 These studies highlighted recurrent conservation of organic compounds in hearth 122 sediments, and attempted to associate them with their natural sources (e.g. plant 123 or animal, terrigenous or marine) even sometimes evoking their specific origin. 124 Moreover, recent studies (Regert, 2011; Kaal et al., 2014) mentioned and 125 illustrated the potential interest of pyrolysis-GC-MS, possibly performed with in 126 situ tetramethylammonium hydroxide derivatization [py(TMAH)-GC-MS], as a 127 tool for the characterization of archaeological OM in pottery. The technique 128 allows determination of the molecular composition of non-extractable OM, which 129 is often the case for thermally altered fireplace residues. It therefore provides a 130 good opportunity to document an OM fraction usually ignored in GC-MS based 131 studies of solvent extracts.

132 This study focuses on the type of fuel used to stoke fireplaces in Late Pleistocene 133 French open air sites. Most of the sites suffered post-depositional phenomena 134 that frequently destroyed the upper part of fire structures, and particularly their 135 fuel remains. As the resulting vestiges are limited mainly to mineral elements 136 showing thermal alteration (e.g. underlying sediment and surrounding stones), 137 their interpretation is challenging. In addition, the recurrent presence of burned 138 bones residues (i.e. from slightly charred to completely calcinated) within the 139 sites, but not always directly on fireplaces, raises the question of their frequent 140 use as a common fuel by Paleolithic societies (Perlès, 1977, Villa et al., 2002). 141 Despite experimental data ascertained the practicability of this use (Théry142 Parisot, 2001 and 2002; Théry-Parisot and Costamagno, 2005; Costamagno et al., 143 2009), the interpretation of archaeological artefacts is still equivocal as numerous 144 others anthropogenic and natural processes can produce burned bones (see 145 Costamagno et al., 2009 for a review).

146 The objectives were thus to establish the geochemical signatures of fireplaces 147 fueled with different materials and to provide a reference dataset for further 148 interpretation of archaeological fireplaces. Experimental fireplaces were realized 149 using wood and/or bone as fuel and compared with the soil layer unaffected by 
150 human practices. The role of the thermal alteration of OM was also tested by 151 analyzing the chemical signature of the soil layer impregnated with unburned 152 animal fat. The chemical composition was determined through organic carbon 153 content $\left(\mathrm{C}_{\text {org }}\right)$ measurement, GC-MS analysis of the lipid extract and py(TMAH)-

154 GC-MS of the bulk OM.

\section{2. Experimental}

\subsection{Study site and sampling}

157 The study was conducted on the aurignacian site of Régismont-le-Haut (ca. $30 \mathrm{Ky}$ 158 BP, southern France; Pradeau et al., 2014) where an experimental protocol has 159 been in place since 2012. The site is at the base of a strongly eroded Miocene calcareous hill, which provides most of the colluvial and aeolian deposits forming

161 the sediment under study. During the Late Pleistocene, these colluvial and 162 aeolian sediments slowly infilled paleochannels carved into the underlying marlstone. This context and the relatively arid climatic conditions led to the formation of a colluvic and calcaric Regosol (IUSS Working Group WRB, 2015; Colluviosol calcaire et carbonaté: AFES, 2008), with few pedogenic features except those linked to the dissolution and precipitation of $\mathrm{CaCO}_{3}$.

167 Experimental fires were set up to mimic several contexts of hypothetical 168 archaeological operation; the main parameter that was varied was fuel type 169 (wood and/or bone). To emulate the context of archaeological fireplaces and avoid modern agricultural induced bias, the experiment was run in realistic open air

171 conditions on a sterile area of the excavated archaeological level, ca. $50 \mathrm{~cm}$ under 172 the plow zone. All experiments and subsequent sampling occurred between

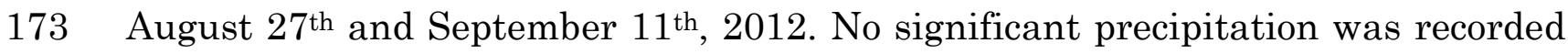
174 on site during this interval; the local meteorological station of Sètes recorded a 175 mean maximal temperature of $28.6{ }^{\circ} \mathrm{C}$ in August and of $23.8^{\circ} \mathrm{C}$ in September and 176 a mean minimal temperature of $21.5{ }^{\circ} \mathrm{C}$ in August and of $17.6{ }^{\circ} \mathrm{C}$ in September. 177 Prior to the experiment a sample of unaffected sediment was collected as a 178 control for the natural organic content and composition in the area (Control).

179 Experiments involved the use of bone and/or pine wood of local origin. The former 180 consisted of up to $15 \mathrm{~cm}$ fragments of steer long bones and pelvic bones (Bos 
181 taurus). The wood included parasol pine (Pinus pinea) dry twigs, small branches 182 and $50 \mathrm{~cm}$ long and up to $10 \mathrm{~cm}$ in diameter logs. For the first experiment, $10 \mathrm{~kg}$ 183 of fragmented steer bones were deposited on the surface of the soil in order to 184 imitate OM impregnation by way of percolation through the sediment. A sample 185 (Soil with bone OM) was collected after a week. The second experiment was with 186 a bone-fueled fireplace (Bone fire) in which $10 \mathrm{~kg}$ of fragmented steer bones were 187 burned. It is noteworthy that a small quantity of pine wood $(<1 \mathrm{~kg})$ was 188 necessary to initiate combustion in this type of hearth (Théry-Parisot and 189 Costamagno, 2005). It operated during $131 \mathrm{~min}$. The third experiment was with a 190 wood-fueled fireplace (Wood fire), in which $5 \mathrm{~kg}$ of dry pine wood were burned 191 during a total operating time of $137 \mathrm{~min}$. Finally, the last experimental fire 192 involved the use of both $5 \mathrm{~kg}$ of pine wood and $3 \mathrm{~kg}$ of bone (Wood+bone fire), to 193 emulate a mixed-fuel fireplace. The total operating time was of $118 \mathrm{~min}$.

194 For the 4 experiments, sampling was conducted following visual distinction of 195 layers (Fig. 1a). Sampling first concerned the altered soil (Upper sub sample, 196 Table 1) but also the underlying and seemingly unaltered soil (Lower sub sample, 197 Table 1). The micro-local organic content was measured to test the significance of 198 the visual layer distinction.

199 Samples were air-dried over two days at $35^{\circ} \mathrm{C}$ (Froilabo-AC120 oven). After 200 manual removing of the most fragile coarse elements (calcitic nodules and 201 organic macroscopic remains such as roots), samples were sieved and the $>2 \mathrm{~mm}$ 202 fraction was discard. Samples were then ground with a mortar and pestle, and 203 eventually with a Retsch-PM200 planetary ball mill (6 min, at $450 \mathrm{rpm}$ ), to pass 204 a $250 \mu \mathrm{m}$ sieve.

206 Due to the naturally high carbonate content of the sediment, acid fumigation was 207 carried out prior to elemental analysis, following Harris et al. (2001). After 208 weighing the samples in Ag foil capsules, they were humidified (15 $\mu$ l deionized 209 water) and placed in a desiccator under vacuum, with a beaker of $\mathrm{HCl}$ (12 M), during $6 \mathrm{~h}$. Lastly, the sample was air-dried for $12 \mathrm{~h}$ at $40{ }^{\circ} \mathrm{C}$. 
211 The $\mathrm{C}_{\text {org }}$ was measured on fumigated samples using an elemental analyzer (Vario

212 PYRO cube, Elementar). To allow $\mathrm{C}_{\text {org }}$ quantification, two $\mathrm{Ag}$ capsules of the

213 same sample were added for a single analysis. The resulting reproducibility was

214 assessed to be between $0.3 \%$ (instrumental) and $0.8 \%$ (methodological).

\subsection{Lipid extraction and GC-MS}

216 Samples for lipid analysis were extracted using an accelerated solvent extractor system (Dionex-ASE100). Between 5 and $7 \mathrm{~g}$ of sediment were placed in a $10 \mathrm{ml}$ 218 Inox cell topped with sterile glass fiber. The extraction program ran at $60{ }^{\circ} \mathrm{C}$, 219 with a static time of $20 \mathrm{~min}$, using dichloromethane/methanol (DCM/MeOH) (2:1, $220 \mathrm{v} / \mathrm{v})$. The extract was concentrated using a rotary evaporator and dried under a gentle $\mathrm{N}_{2}$ flow, dissolved in DCM in a $1,5 \mathrm{ml}$ vial with a PTFE screw cap and stored at $4{ }^{\circ} \mathrm{C}$ until analysis (adapted from Quénéa et al., 2012)

223 Each extract was analyzed with an Agilent 6890 gas chromatograph coupled to an Agilent 5973N mass spectrometer using electron ionization at $70 \mathrm{eV}$. The GC instrument was equipped with a $30 \mathrm{~m}$ Restek 5 Sil MS column (i.d. $0.25 \mathrm{~mm}$, film thickness $0.5 \mu \mathrm{m})$. The carrier gas was He, at a constant flow rate of $1 \mathrm{ml} / \mathrm{min}$. Samples were injected splitless with the injector at $300{ }^{\circ} \mathrm{C}$. The oven temperature was programmed from $80{ }^{\circ} \mathrm{C}(0.5 \mathrm{~min})$ to $100{ }^{\circ} \mathrm{C}$ at $10{ }^{\circ} \mathrm{C} / \mathrm{min}$ then to $320{ }^{\circ} \mathrm{C}$ at 4 ${ }^{\circ} \mathrm{C} / \mathrm{min}$. Compound assignment was based on comparison with published data (references thereafter in the text) and the NIST mass spectral library.

The whole device was operated with a Gerstel multipurpose sampler (MPS) and

232 Gerstel Maestro software. The workflow included derivatization of extracts by 233 adding 10\% (v/v) BSTFA [N,O-bis(trimethylsilyl)trifluoroacetamide] and heating at $60{ }^{\circ} \mathrm{C}$ for $10 \mathrm{~min}$ to obtain trimethylsilylated (TMS) derivatives.

236 Bulk OM from the upper subsample was characterized through Curie-Point 237 pyrolysis (Pilodist) coupled to a GC (Thermo Trace - 30 m RXI 5 Sil MS capillary 238 column, i.d. $0.25 \mathrm{~mm}$, film thickness $0.5 \mu \mathrm{m}$ with Integra guard column) and a 239 MS (DSQ). Samples mixed with TMAH (25\% w/v in $\mathrm{MeOH})$ were loaded in a 240 ferromagnetic tube and pyrolyzed for $9.9 \mathrm{~s}$ at $650{ }^{\circ} \mathrm{C}$ under a $1 \mathrm{ml} / \mathrm{min}$ He flow 
241 (adapted from Quénéa et al., 2005). The pyrolysis products were separated in the

$242 \mathrm{GC}$ system, where the temperature of the $\mathrm{GC}$ oven was held at $50{ }^{\circ} \mathrm{C}$ for $10 \mathrm{~min}$,

243 before an increase at $2{ }^{\circ} \mathrm{C} / \mathrm{min}$ to $310^{\circ} \mathrm{C}$. The ion source of the mass spectrometer 244 was at $220{ }^{\circ} \mathrm{C}$, which was set to scan from $\mathrm{m} / z 35$ to 800 . The total ion current

245 (TIC) trace was recorded and products of pyrolysis identified using comparison 246 with published data (references thereafter in the text) and the mass spectral 247 NIST library.

\section{Results and discussion}

\subsection{Macroscopic features and $C_{\text {org }}$ variations}

250 The Control displayed general features illustrative of the local soil type: a 251 homogenous sandy loam with numerous calcitic features and few organic macro252 elements (Table 1$)$. An expected low $\mathrm{C}_{\text {org }}(0.3 \%)$ was measured and was consistent 253 with that of the four lower subsamples $(0.3 \pm 0.1 \%)$ collected below each 254 experimental structures. This result validated the visual identification of fire255 affected soil layers and supported the low soil variability needed to track 256 variables influenced by the experimental parameters.

257 On the contrary, most of the experiments led to an increase in the organic content of upper subsamples (Table 1). In the Soil with bone OM, a $2 \mathrm{~cm}$ deep

259 impregnation of the sediment was observed on the surface (Fig. 1b) and in section. During the experiment, OM (likely bone marrow) leaked from the bone

261 fragments and was responsible for the impregnation, as well as the increase in $262 \mathrm{C}_{\text {org}}$, which reached $4.7 \%$. The macroscopic visual aspects of the Bone fire 263 consisted of an irregular shaped darkened and hardened hearth covered with carbonized to calcinated bones. Vertically, the sediment was affected by the combustion down to $4 \mathrm{~cm}$ depth, displaying darkening and reddening. During the

266 operation, a significant leakage of organic fluid was observed around the structure (Fig. 1c) and was also noted vertically on the structure's periphery. The 268 leakage resulted in a slightly lower increase of $\mathrm{C}_{\text {org }}(2.3 \%)$ than for the Soil with 269 bone $O M$. The phenomenon can likely be explained by a shorter interaction time between the soil and the bone OM, as well as the combustion process that likely 
operation of the Wood fire resulted in a circular (ca. $50 \mathrm{~cm}$ diam.) collection of ash and charcoal overlying a reddened sediment (Fig. 1e). This reddening was 0.5 to $1.5 \mathrm{~cm}$ deep. No significant difference was detected in the $\mathrm{C}_{\text {org }}$ of this reddened sediment compared with the Control, likely because the coarse fraction, which may have included some combustion residue, was discarded during sample collection and preparation. The results of the Wood+bone fire experiment were, unsurprisingly, intermediate between those from other experimental fireplaces. A superficial covering, consisting logically of a mix of wood and bone combustion residue, capped the structure (Fig. 1d). Vertically, the structure displayed a 1 to $2.5 \mathrm{~cm}$ deep reddening, whose first $1 \mathrm{~cm}$ was heavily influenced by the combustion residues, leaving a darkened layer whose reddened nature was not visible to the naked eye (Table 1$)$. Despite the $\mathrm{C}_{\text {org }}(0.9 \%)$ did not prove to be significantly higher than the $\mathrm{C}_{\text {org }}$ of the Wood fire (or Control), the value was intermediate between the Wood Fire and the Bone fire, what seemed coherent with the field observation of a lower input of bone OM due to 1) a lower quantity of bone used as fuel and 2) the formation of wood embers that might have prevented OM leakage into the soil by increasing the efficiency of combustion.

\subsection{Local organic background}

In accord with its low $\mathrm{C}_{\mathrm{org}}$, the Control did not present any detectable component from py(TMAH)-GC-MS analysis. No phenol, lignin-derived components, or long chain alkanes/alkenes and acids, traditionally seen in the pyrolysis products of natural soil OM (Hempfling and Schulten, 1990), were visible in the archaeological soil layer. Lipids detected from GC-MS were diverse, yet present in such low concentration as to render them negligible. The identification of such a diversified lipid fraction was made possible through a higher concentration of sample during preparation. The absence of a significant organic signal confirmed its suitability as a control for the experiments that followed.

\subsection{Sources of organic compounds}

301 The saturated $n$-acids from $\mathrm{C}_{6: 0}$ to $\mathrm{C}_{18: 0}$, dominated by $\mathrm{C}_{16: 0}$ and $\mathrm{C}_{18: 0}$, and 302 monomethylated acids, were ubiquitous in both lipid extracts and 
303 thermochemolysis products (Figs. 2 and 3, Tables 2 and 3). Their presence in all 304 the samples might reflect animal, plant and microbial biomass origins. 305 Nevertheless, the $\mathrm{C}$ chain distribution appeared more specific, especially the high 306 relative proportion of short-chain fatty acids in Soil with bone OM, and is 307 discussed later.

308 Due to its widespread occurrence in animal tissue (Christie, 2014) cholesterol can 309 be considered as an indicator of an animal contribution to lipid extracts, but a 310 fungal or even bacterial origin cannot be completely excluded (Huang and 311 Meinschein, 1976; Volkman, 2005; Christie, 2014). These last two elements were 312 likely the source of cholesterol [25] in the Control (Fig. 2a) and the Wood fire (Fig. $3132 \mathrm{e})$.

314 The significant contribution of $\mathrm{Me}-\mathrm{C}_{15}$ and $\mathrm{Me}-\mathrm{C}_{17}$ acids (iso and anteiso) to the 315 lipids and py(TMAH)-GC-MS trace of the Soil with bone OM (Figs. 2b and 3a ), 316 the Bone fire (Figs. 2c and 3b) and the Wood+bone fire (Figs. 2d and 3c), might 317 point to a fungal and bacterial OM signature (Saiz-Jimenez and De Leeuw, 1986; 318 Dudd et al., 1998; Kanthilatha et al., 2014; Spangenberg et al., 2014). However 319 those branched acids can also be produced by bacteria in ruminant intestines 320 (Dudd et al., 1999; Christie, 2014) and an animal origin can not be ruled out in 321 the context of these experiments.

322 The presence of squalene [24], a precursor of numerous sterols, might have a 323 natural origin in the extract of the Control (Fig. 2a) and the Wood fire (Fig. 2e). 324 However, it is also a broadly-used plasticizer, so in-situ or handling 325 contamination could not be totally dismissed (Evershed, 1993; Heron et al., 326 2010).

\subsubsection{Plant $O M$}

328 The presence of stigmasterol [26] and sitosterol [28], both common phytosterols 329 (Huang and Meinschein, 1976), and of taraxerone [27], $\alpha$-amyrone [29], and 330 lupenone [30] in the extract of the Control (Fig. 2a) point to a significant 331 contribution from plant OM (Vilegas et al., 1997; Mathe et al., 2004; Simoneit, 332 2005; Hernández-chávez et al., 2012). The contribution of aliphatic compounds 
333 with relatively long chains is commonly considered to reflect a plant-derived OM 334 origin. In the extract of the Control (Fig. 2a) and Wood fire (Fig. 2e), the $n$ 335 alkanes $\left(\mathrm{C}_{21}, \mathrm{C}_{29}, \mathrm{C}_{31}\right.$ and $\left.\mathrm{C}_{33}\right)$ might be attributed to an plant epicuticular wax 336 origin (Spangenberg et al., 2014), whereas $n$-alcohols longer than $\mathrm{C}_{17}$, and saturated $n$-acids longer than $\mathrm{C}_{18}$, support the assignment of slightly altered plant derived compounds (Evershed et al., 1999; Poirier et al., 2005). Finally, phenol derivatives [4 and 8] and benzoic acids [1 and 3] in the Wood+bone fire (Fig. 2d) and the Wood fire lipids (Fig. 2e) highlight byproducts of lignin degradation (Simoneit et al., 1993; Quenea et al., 2004; Simoneit, 2005; Regert et al., 2006; Shadkami and Helleur, 2010).

343 As the phenolic and benzoic compounds were only recovered in Wood+bone fire and Wood fire (Table 4), they may be illustrative of the contribution of the wood OM used as fuel to the organic signatures of these experiments (March et al., 2014).

\subsubsection{Thermally-altered plant $O M$}

348 Aromatic compounds such as benzene derivatives ([5] to [10]) in the py(TMAH)GC-MS trace of the Wood+bone fire (Fig. 3c) and the Wood fire (Fig. 3d), as well as naphthalene [10] in the extract of the Wood fire (Fig. 2e), reflect a high degree of OM carbonization (Simoneit et al., 1993; Knicker et al., 2005; Kaal et al., 2009; Alexis et al., 2012; De la Rosa et al., 2012). This type of compounds could also result from artefact production by Curie point pyrolysis from carbohydrates, as observed by Pastorova et al. (1994). However it is noteworthy that in the present study, the benzene and naphthalene derivatives were only detected in the experiments involving wood as dominant fuel and that the numerous furan and pyranone derivatives expected in cellulose pyrolysis were not detected (Table 4).

358 This result suggests that they likely come from carbonized wood residues. 359 Moreover the absence of odd $\mathrm{C}$ chain predominance in the alkane series in the Wood fire extract (Fig. 2e) could also be indicative of the thermal alteration process of wood fuel OM (Eglinton and Calvin, 1967; Wiesenberg et al., 2009; De la Rosa et al., 2012; March et al., 2014). 
363 Many of these compounds were readily documented in GC-MS and py-GC-MS 364 studies of forest fire sediments (e.g. Knicker et al., 2005). Their observation in 365 fireplace context validates the crossing of results between these close fields of 366 research. Finally, their association in wood fueled fires with compounds specific 367 of uncharred wood OM (Table 4) provides a good overall signature for this type of 368 fire operation.

\subsubsection{Bone $O M$}

In the Soil with bone $O M$ and the Bone fire, the dimethoxypropanol [1], trimethoxypropane [2], saturated and unsaturated $n$-acids, diacids, epoxy- [13], and (di)hydroxyacids ([12] and [14] to [17]) were detected from py(TMAH)-GC-MS (Figs. 3a and b). Monoacylglycerol [15, 17, 19 to 23] and diacylglycerol [31 and 32] were observed in the extract (Figs. $2 \mathrm{~b}$ and c). These compounds likely resulted from triacylglycerol degradation (Dudd et al., 1998; Evershed et al., 2002; Van Den Berg et al., 2002). They could originate from plant (Van Den Berg et al., 2002; Maher and Bressler, 2007) or animal fats (Evershed et al., 2002; Ben Hassen-Trabelsi et al., 2014). However, the presence of $n$-acid $\mathrm{C}_{18: 1}$, one of the most important $n$-acid in animal fat (Malainey et al., 1999; Nieuwenhuyse et al., 2015), points to the latter origin. Moreover, several compounds likely reflect the contribution of fat degraded by hydrolysis or oxidation. The short chain $n$-acids $\left(\mathrm{C}_{8}\right.$ and $\left.\mathrm{C}_{9}\right)$ and monomethyl branched unsaturated acids $\left(\mathrm{Me}-\mathrm{C}_{9}\right.$ and $\left.\mathrm{Me}-\mathrm{C}_{10}\right)$ in the py(TMAH)-GC-MS products (Figs. 3a and b), as well as the short chain diacids $\left(\mathrm{C}_{4}\right.$ to $\left.\mathrm{C}_{11}\right)$ and $n$-acid $\left(\mathrm{C}_{8}\right.$ and $\left.\mathrm{C}_{9}\right)$ in the lipid extract (Figs. $2 \mathrm{~b}$ and $\mathrm{c}$ ), could originate from drying and/or oxidation of unsaturated $n$-acids (Wexler, 1964; Mills, 1966; Erhardt, 1998; Van Den Berg et al., 2002; Rontani and Aubert, 2008).

These compounds were all present in the Soil with bone $O M$ and occasionally present in Bone fire and Wood+bone fire (Table 4). Those results were in accordance with existing references on animal fat (e.g. Evershed et al., 2002), despite short-chain methyl branched acids have been rarely described in such context. Moreover, the functioning of the fire seems to induce an important reduction of the number of recovered diagnostic compounds. 
395 In the py(TMAH)-GC-MS TIC traces of the Bone fire (Fig. 3b) and of the 396 Wood+bone fire (Fig. 3c), the short chain $n$-alkane/n-alkene doublets could be 397 related to thermal degradation processes (Almendros et al., 1988; Nawar, 1989; 398 Simoneit, 2002; Eckmeier and Wiesenberg, 2009; Wiesenberg et al., 2009). In the 399 extract of the same samples (Figs. 2c and d), the series of short chain 400 monomethyl branched diacids $\left(\mathrm{C}_{4}\right.$ to $\left.\mathrm{C}_{10}\right)$, short chain $n$-alcohols $\left(<\mathrm{C}_{17}\right)$, oxoacids, 401 as well as ketones $\left(\mathrm{C}_{14}\right.$ to $\mathrm{C}_{17}$ and $\mathrm{C}_{29}, 31,33$ and 35$)$ and lactones [13 and 14] were 402 also common markers of, more specifically, animal OM thermal degradation 403 (Nawar, 1989; Evershed et al., 2002). Ketones and Y-lactones are frequently 404 reported in thermally altered OM and are usually attributed to animal-fat and 405 meat degradation by heating (Nawar, 1969; Evershed et al., 1995). In this 406 context, the triacylglycerols and $n$-acids are both sources of the long chain ketones, whereas short chain methyl ketones are considered to be secondary products formed during more intense heating. Besides, the Y-lactones are formed by cyclisation of hydroxyacids following dehydration upon thermal stress (Nawar,

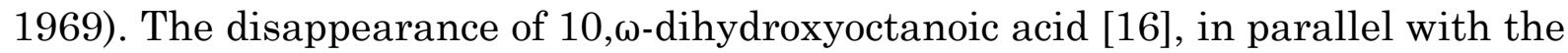

411 formation of Y-lactones [13 and 14] in Bone fire (Fig. 2c) compared with Soil with 412 bone $O M$ (Fig. 2b) might be illustrative of this process.

413 The Bone fire and Wood+bone fire provide a signature specific to the use of bone 414 as fuel (Table 4). It is characterized by markers of animal fat heating, resulting 415 from the melting and the burning of marrow initially contained in the bones. Yet, 416 it is noteworthy that, to our knowledge, the formation of short monomethyl 417 branched diacids $\left(\mathrm{C}_{4}\right.$ to $\left.\mathrm{C}_{10}\right)$, short chain $n$-alcohols $\left(<\mathrm{C}_{17}\right)$ and oxoacids is little 418 known in this context.

\subsection{Archaeological implications}

420 In order to apply this reference dataset to archaeological contexts, the recovery of 421 previously identified organic signatures has to be questioned. As stated by March 422 et al. (2014), post-depositional processes may occur, namely the potential 423 pollution through input of more recent $\mathrm{OM}$ and the degradation processes that 424 likely affect the archaeological organic residues. 
425 First, the pollution issue regards both natural and anthropogenic agents. Natural ones are mostly linked to sedimentary covering of archaeological site and pedogenic processes such as bioturbation and are unavoidable. Additionally, this type of pollution will most likely correspond to vegetal OM lacking thermal alteration byproducts and displaying a weak maturity allowing its recognition (March et al. 2014). Anthropogenic pollution can be related either to agricultural 431 practices or to contamination related to archaeological excavation and sampling. 432 As for agricultural input, markers are generally well known and easily 433 identifiable. They may correspond to modern practices (chemical fertilized), 434 which will not interfere with our compounds of interest, and to manuring (like 435 coprostanol; Evershed et al., 2001). However, conjoint collection of control samples both in stratigraphy and planimetry allows definition of the local soil organic background (e.g. Heron et al., 1991).

438 Secondly, the ability of the signatures to be preserved over time is uncertain. 439 Except from the work of March et al. (2014), this central matter has been rarely explored in the specific case of fireplaces, despite substantial documentation exists in the field of the aging of fire affected soil OM (e.g. Knicker, 2011) and organic residues in pottery (e.g. Malainey, 2007). Labile compounds such as unsaturated $n$-acids or short-chain saturated $n$-acids are unlikely to survive long 444 period of time (Eglinton et al., 1991). In contrary, due to their relative 445 recalcitrance, aromatic compounds originating from lignin (benzoic acids, 446 phenols) and from charring processes (benzene and naphthalene derivatives) are 447 expected to remain in soil at long timescale (Baldock et al., 2004; Lützow et al., 448 2006; Marschner et al., 2008). Lipids were also reported to present decreasing stability following the order: alkanes, alkanones, sterols, $n$-alkanoic acids (especially $>\mathrm{C}_{20}$ ), $n$-alkanols and $n$-alkenoic acids (Cranwell, 1981). Based on this 451 chemical property, among previously identified signatures the best candidates for 452 recovery after millennia are 1 ) ketones and $n$-alkane/n-alkene doublets for Bone 453 fire, 2) saturated $n$-acids longer than $\mathrm{C}_{18}$, benzoic acids, ketones, benzene 454 derivatives and $n$-alkane/n-alkene doublets for Wood and bone fire and 3) 455 saturated $n$-acids longer than $\mathrm{C}_{18}, n$-alkanes, benzoic acids, phenolic compounds 
and benzene derivatives for Wood fire, whereas no compound is expected to remain in Soil with bone OM (Table 4).

458 Nevertheless, the relevance of recalcitrance alone to predict the residence time of compounds has been widely discussed (Marschner et al., 2008; Bol et al., 2009; Kleber et al., 2011). Rather, the spatial inaccessibility or the organo-mineral interactions seem determinant for preservation at long timescale or in subsoil 462 horizon (Lützow et al., 2006). More specifically, in calcareous soils like at 463 Régismont-le-Haut, the high polyvalent cation content may induce the formation of cation bridges, leading to stabilization of organic residues (Lützow et al., 2006; 465 Grünewald et al., 2006). However, no effect of $\mathrm{CaCO}_{3}$ and $\mathrm{pH}$ on mineralization could be observed by Bertrand et al. (2007), questioning the significance of this stabilization mechanism. In this fireplace context, the association with charcoal might also limit the decomposition (Hernandez-Soriano et al., 2016), in this case, mainly through physical protection. Finally, as the substrate limitation can be considered as the main contributing factor of organic matter stabilization in deep soil horizons (Marschner et al., 2008), burial underwent by archaeological level could then have favored various compound preservation. For example, in prehistoric contexts, diacids were documented through GC-MS, in addition to long chain ketones and $\mathrm{Y}$-lactones in Pincevent site fireplace sediments and heated stones (ca. $14 \mathrm{Ky}$ cal. BP, Lucquin, 2007). Short chain diacids were also mentioned in the GC-MS study of sediments related to thermal fat processing in Alaska (ca. 5 Ky BP, Buonasera et al. 2015). In the same geographical context, the study of sediments from fireplaces (ca. 14 Ky cal. BP, Kedrowsky et al. 2009) illustrated the preservation of several branched $n$-acids interpreted as resulting from lipid degradation by bacteria or from ruminant fat. The recovery of compounds similar to those detected in this work, but with various intrinsic recalcitrance, could illustrate the importance of physical conditions for the record 483 of organic signatures.

\section{Conclusion}

485 This study provides the organic signature of different experimental fireplaces and demonstrates that they allow distinguishing if bone and/or wood were used as 
fuel. It confirms that the thermal alteration of OM significantly modifies the initial signature of the unburned material, limiting the direct use of markers from unaltered sources to reconstruct fuel nature in archaeological fireplaces. In contrary, several byproducts of thermal degradation can serve as indicators of fuel type and, in this respect, the use of Py(TMAH)-GC-MS for the identification of non-extractable compounds proved particularly adapted. However, because of 493 the variable organic components that constituted the organic signatures of the

494 fireplaces, their differential preservation has to be expected. Their intrinsic recalcitrance, as well as the local environment and depositional context, might influence the recovery of the chemical signatures under investigation. Consequently, when applying this type of reference dataset to archaeological samples, which likely underwent substantial post-depositional processes, caution is needed. Nevertheless, as many identified compounds were found within nonextractable or recalcitrant OM fraction in our study, and subject to the collection of control samples, the reconstruction of archaeological interpretable signatures based on this referential dataset seems possible.

\section{Acknowledgements}

504 The project was supported by the Partner University Fund, in collaboration with 505 the New York University (Aurignacian Genius project, 2011-2014) and the 506 funding from the French Ministère de la Culture et de la Communication (Service 507 Régional d'Archéologie du Languedoc-Roussillon) and from the Conseil 508 Départemental de l'Hérault. We thank R. Mensan for help during fieldwork, C. 509 Anquetil and V.Vaury for technical assistance, S. Derenne and L.E. Anderson for 510 editing. Finally, we are also grateful to editors and two anonymous reviewers for 511 their constructive and helpful comments.

\section{$512 \quad$ References}

513 AFES (Association Française pour l'Etude des Sols), 2008. Référentiel $514 \quad$ Pédologique. Quae, Versailles, France.

515 Aldeias, V., Dibble, H.L., Sandgathe, D., Goldberg, P., McPherron, S.J.P., 2016. 516 How heat alters underlying deposits and implications for archaeological fire 517 features: A controlled experiment. Journal of Archaeological Science 67, 64- 
Alexis, M., Rasse, D.P., Knicker, H., Anquetil, C., Rumpel, C., 2012. Evolution of soil organic matter after prescribed fire: A 20-year chronosequence. Geoderma 189-190, 98-107. doi:10.1016/j.geoderma.2012.05.003

Almendros, G., Martín, F., González-Vila, F.J., 1988. Effects of fire on humic and lipid fractions in a Dystric Xerochrept in Spain. Geoderma 42, 115-127. doi:10.1016/0016-7061(88)90028-6

Baldock, J.A., Masiello, C.A., Gélinas, Y., Hedges, J.I., 2004. Cycling and composition of organic matter in terrestrial and marine ecosystems. Marine Chemistry 92, 39-64. doi:10.1016/j.marchem.2004.06.016

Barnard, H., Ambrose, S.H., Beehr, D.E., Forster, M.D., Lanehart, R.E., Malainey, M.E., Parr, R.E., Rider, M., Solazzo, C., Yohe, R.M., 2007. Mixed results of seven methods for organic residue analysis applied to one vessel with the residue of a known foodstuff. Journal of Archaeological Science 34, 28-37. doi:10.1016/j.jas.2006.03.010

Barnard, H., Eerkens, J.W., 2007. Theory and Practice of Archaeological Residue Analysis. Archaeopress BAR Internationnal Series 1650, Oxford, UK.

Bellomo, R., 1993. A methodological approach for identifying archaeological evidence of fire resulting from human activities. Journal of Archaeological Science 20, 525-553. doi:10.1006/jasc.1993.1033

Ben Hassen-Trabelsi, A., Kraiem, T., Naoui, S., Belayouni, H., 2014. Pyrolysis of waste animal fats in a fixed-bed reactor: production and characterization of bio-oil and bio-char. Waste Management 34, 210-8. doi:10.1016/j.wasman.2013.09.019

Bertrand, I., Delfosse, O., Mary, B., 2007. Carbon and nitrogen mineralization in acidic, limed and calcareous agricultural soils: Apparent and actual effects. Soil Biology and Biochemistry 39, 276-288. doi:10.1016/j.soilbio.2006.07.016

Bol, R., Poirier, N., Balesdent, J., Gleixner, G., 2009. Molecular turnover time of soil organic matter in particle-size fractions of an arable soil. Rapid Communications in Mass Spectrometry 23, 2551-2558. doi:10.1002/rcm.4124

Buonasera, T., 2005. Fatty acid analysis of prehistoric burned rocks: a case study from central California. Journal of Archaeological Science 32, 957-965. doi:10.1016/j.jas.2005.01.012

Buonasera, T., Tremayne, A.H., Darwent, C.M., Eerkens, J.W., Mason, O.K., 2015. Lipid biomarkers and compound specific $\delta 13 \mathrm{C}$ analysis indicate early development of a dual-economic system for the Arctic Small Tool tradition in 
Northern Alaska. Journal of Archaeological Science 61, 129-138. doi:10.1016/j.jas.2015.05.011

Canti, M.G., 2003. Aspects of the chemical and microscopic characteristics of plant ashes found in archaeological soils. Catena 54, 339-361. doi:10.1016/S0341-8162(03)00127-9

Christie, W.W., 2014. Cholesterol - Structure, Occurence, Physical Properties and Function [WWW Document]. A Lipid Primer - AOCS Lipid Library. URL http://lipidlibrary.aocs.org/Primer/content.cfm?ItemNumber=39303

Costamagno, S., Théry-Parisot, I., Castel, J.-C., Brugal, J.-P., 2009. Combustible ou non? Analyse multifactorielle et modèles explicatifs sur des ossements brûlés paléolithiques. In: Théry-Parisot, I., Costamagno, S., Henry, A. (Eds.), Gestion Des Combustibles Au Paléolithique et Au Mésolithique: Nouveaux Outils, Nouvelles Interprétations, Lisbon, 2006. Archaeopress BAR International Series 1914, Oxford, UK, pp. 47-60.

Coudret, P., Larrière, M., Valentin, B., 1989. Comparer les foyers: une entreprise difficile. In: Olive, M., Taborin, Y. (Eds.), Nature et Fonction des Foyers Préhistorique, Nemours, 1987. APRAIF, Nemours, France, pp. 37-45.

Cranwell, P.A., 1981. Diagenesis of free and bound lipids in terrestrial detritus deposited in a lacustrine sediment. Organic Geochemistry 3, 79-89. doi:10.1016/0146-6380(81)90002-4

De la Rosa, J.M., Faria, S.R., Varela, M.E., Knicker, H., González-Vila, F.J., González-Pérez, J.A., Keizer, J., 2012. Characterization of wildfire effects on soil organic matter using analytical pyrolysis. Geoderma 191, 24-30. doi:10.1016/j.geoderma.2012.01.032

Dudd, S.N., Regert, M., Evershed, R.P., 1998. Assessing microbial lipid contributions during laboratory degradations of fats and oils and pure triacylglycerols absorbed in ceramic potsherds. Organic Geochemistry 29, 1345-1354. doi:10.1016/S0146-6380(98)00093-X

Dudd, S.N., Evershed, R.P., Gibson, A.M., 1999. Evidence for varying patterns of exploitation of animal products in different prehistoric pottery traditions based on lipids preserved in surface and absorbed residues. Journal of Archaeological Science 26, 1473-1482. doi:10.1006/jasc.1998.0434

Eckmeier, E., Wiesenberg, G.L.B., 2009. Short chain n-alkanes $\left(\mathrm{C}_{16-20}\right)$ in ancient soil are useful molecular markers for prehistoric biomass burning. Journal of Archaeological Science 36, 1590-1596. doi:10.1016/j.jas.2009.03.021

Eglinton, G., Calvin, M., 1967. Chemical fossils. Scientific American 216, 32-43. 
Eglinton, G., Logan, G.A., Ambler, R.P., Boon, J.J., Perizonius, W.R.K., 1991. Molecular preservation. Philosophical transactions of the Royal Society of London. Series B, Biological sciences 333, 315-27; discussion 327-8. doi:10.1098/rstb.1991.0081

595

Erhardt, D., 1998. Painted based on drying-oil media. In: Dorge, V., Carey Howlett, F. (Eds.), Painted Wood: History and Conservation, Williamsburg, Virginia 1994. The J. Paul Getty Trust, Los Angeles, USA, pp. 17-32.

Evershed, R.P., 1993. Biomolecular archaeology and lipids. World Archaeology 25, 74-93. doi:10.1080/00438243.1993.9980229

Evershed, R.P., 2008. Organic residue analysis in archaeology: the archaeological biomarker revolution. Archaeometry 50, 895-924. doi:10.1111/j.14754754.2008.00446.x

Evershed, R.P., Dudd, S.N., Charters, S., Mottram, H., Stott, A.W., Raven, A., Bergen, P.F. Van, Bland, H.A., Jones, M., Bada, J., 1999. Lipids as carriers of anthropogenic signals from prehistory [and Discussion]. Philosophical Transactions: Biological Sciences 354, 19-31.

Evershed, R.P., Dudd, S.N., Copley, M.S., Berstan, R., Stott, A.W., Mottram, H., Buckley, S. A., Crossman, Z., 2002. Chemistry of archaeological animal fats. Accounts of Chemical Research 35, 660-668. doi:10.1021/ar000200f

Evershed, R.P., Dudd, S.N., Lockheart, M.J., Jim, S., 2001. Lipids in archaeology. In: Brothwell, D.R., Pollard, A.M. (Eds.), Handbook of Archaeological Sciences. Wiley, Chichester, UK, pp. 331-349.

Evershed, R.P., Stott, A.W., Raven, A., Dudd, S.N., Charters, S., Leyden, A., 1995. Formation of long-chain ketones in ancient pottery vessels by pyrolysis of acyl lipids. Tetrahedron Letters 36, 8875-8878. doi:10.1016/00404039(95)01844-8

Grünewald, G., Kaiser, K., Jahn, R., Guggenberger, G., 2006. Organic matter stabilization in young calcareous soils as revealed by density fractionation and analysis of lignin-derived constituents. Organic Geochemistry 37, 15731589. doi:10.1016/j.orggeochem.2006.05.002

Harris, D., Horwáth, W.R., van Kessel, C., 2001. Acid fumigation of soils to remove carbonates prior to total organic carbon or carbon-13 isotopic analysis. Soil Science Society of America Journal 65, 1853. doi:10.2136/sssaj2001.1853

Hempfling, R., Schulten, H.-R., 1990. Chemical characterization of the organic matter in forest soils by Curie point pyrolysis-GC/MS and pyrolysis-field 
ionization mass spectrometry. Organic Geochemistry 15, 131-145. doi:10.1016/0146-6380(90)90078-E

628

629

630

631

632

633

634

635

636

637

638

639

640

641

642

643

644

645

646

647

648

649

650

651

652

653

654

655

656

657

658

659

660

661

Henry, A., Théry-Parisot, I., 2014. From Evenk campfires to prehistoric hearths: charcoal analysis as a tool for identifying the use of rotten wood as fuel. Journal of Archaeological Science 52, 321-336. doi:10.1016/j.jas.2014.09.005

Hernández-Chávez, I., Torres-Tapia, L.W., Simá-Polanco, P., Cedillo-Rvera, R., Moo-Puc, R., Peraza-Sánchez, S.R., 2012. Antigiardial activity of Cupania dentata bark and its constituents. Journal of the Mexican Chemical Society $56,105-108$.

Hernandez-Soriano, M.C., Kerré, B., Goos, P., Hardy, B., Dufey, J., Smolderd, E., 2016. Long-term effect of biochar on the stabilization of recent carbon: soils with historical inputs of charcoal. Global Change Biology Bioenergy 8, 371381. Doi:10.1111/gcbb.12250

Heron, C., Evershed, R.P., Goad, L.J., 1991. Effects of migration of soil lipids on organic residues associated with buried potsherds. Journal of Archaeological Science 18, 641-659. doi:10.1016/0305-4403(91)90027-M

Heron, C., Nilsen, G., Stern, B., Craig, O., Nordby, C., 2010. Application of lipid biomarker analysis to evaluate the function of "slab-lined pits" in Arctic Norway. Journal of Archaeological Science 37, 2188-2197. doi:10.1016/j.jas.2010.03.016

Huang, W.-Y., Meinschein, W.G., 1976. Sterols as source indicators of organic materials in sediments. Geochimica et Cosmochimica Acta 40, 323-330. doi:10.1016/0016-7037(76)90210-6

IUSS Working Group WRB, 2015. World reference base for soil resources 2014, update 2015. International soil classification system for naming soils and creating legends for soil maps. World Soil Resources Reports No. 106. doi:10.1017/S0014479706394902

Kaal, J., Lantes-Suarez, O., Martinez Cortizas, A., Prieto, B., Prieto Martinez, M.-P., 2014. How useful is pyrolysis-GC/MS for the assessment of molecular properties of organic matter in archaeological pottery matrix? An exploratory case study from North-West Spain. Archaeometry 56, 187-207. doi:10.1111/arcm.12057

Kaal, J., Martínez Cortizas, A., Nierop, K.G.J., 2009. Characterisation of aged charcoal using a coil probe pyrolysis-GC/MS method optimised for black carbon. Journal of Analytical and Applied Pyrolysis 85, 408-416. doi:10.1016/j.jaap.2008.11.007 
Kanthilatha, N., Boyd, W., Dowell, A., Mann, A., Chang, N., Wohlmuth, H., Parr, J., 2014. Identification of preserved fatty acids in archaeological floor sediments from prehistoric sites at Ban Non Wat and Nong Hua Raet in northeast Thailand using gas chromatography. Journal of Archaeological Science 46, 353-362. doi:10.1016/j.jas.2014.03.033

Kedrowski, B.L., Crass, B. A., Behm, J. A., Luetke, J.C., Nichols, A. L., Moreck, A. M., Holmes, C.E., 2009. GC/MS analysis of fatty acids from ancient hearth residues at the Swan Point archaeological site. Archaeometry 51, 110-122. doi:10.1111/j.1475-4754.2008.00384.x

Kleber, M., Nico, P.S., Plante, A., Filley, T., Kramer, M., Swanston, C., Sollins, P., 2011. Old and stable soil organic matter is not necessarily chemically recalcitrant: Implications for modeling concepts and temperature sensitivity. Global Change Biology 17, 1097-1107. doi:10.1111/j.1365-2486.2010.02278.x

Knicker, H., 2011. Pyrogenic organic matter in soil: its origin and occurrence, its chemistry and survival in soil environments. Quaternary International 243, 251-263. doi:10.1016/j.quaint.2011.02.037

Knicker, H., González-Vila, F.J., Polvillo, O., González, J. a., Almendros, G., 2005. Fire-induced transformation of C- and N- forms in different organic soil fractions from a Dystric Cambisol under a Mediterranean pine forest (Pinus pinaster). Soil Biology and Biochemistry 37, 701-718. doi:10.1016/j.soilbio.2004.09.008

Lucquin, A., 2007. Étude Physico-Chimique des Méthodes de Cuisson Pré- et Protohistoriques. PhD dissertation, Université Rennes 1, France.

Lützow, M. V., Kögel-Knabner, I., Ekschmitt, K., Matzner, E., Guggenberger, G., Marschner, B., Flessa, H., 2006. Stabilization of organic matter in temperate soils: Mechanisms and their relevance under different soil conditions - A review. European Journal of Soil Science 57, 426-445. doi:10.1111/j.13652389.2006.00809.x

Maher, K.D., Bressler, D.C., 2007. Pyrolysis of triglyceride materials for the production of renewable fuels and chemicals. Bioresource Technology 98, 2351-2368. doi:10.1016/j.biortech.2006.10.025

Malainey, M.E., 2007. Fatty acid analysis of archaeological residues: procedures and possibilities. In: Barnard, H., Eerkens, J.W. (Eds.), Theory and Practice of Archaeological Residue Analysis. Archeopress BAR Intenational Series 1650, pp. 77-89.

Malainey, M.E., Przybylski, R., Sherriff, B.L., 1999. The fatty acid composition of 
Native food plants and animals of Western Canada. Journal of Archaeological Science 26, 83-94. doi:10.1006/jasc.1998.0305

Mallol, C., Hernández, C.M., Cabanes, D., Machado, J., Sistiaga, A., Pérez, L., Galván, B., 2013. Human actions performed on simple combustion structures: An experimental approach to the study of Middle Palaeolithic fire. Quaternary International 315, 3-15. doi:10.1016/j.quaint.2013.04.009

March, R.J., 1995. Méthodes Physiques et Chimiques Appliquées à l'Etude des Structures de Combustion Préhistoriques. L'Approche par la Chimie Organique. PhD dissertation, Université Paris 1, France.

March, R.J., 2013. Searching for the functions of fire structures in Eynan (Mallaha) and their formation processes: a geochemical approach. In: BarYosef, O., Valla, F. (Eds.), Natufian Foragers in the Levant. Terminal Pleistocene Social Changes in Western Asia. International Monographs in Prehistory 19, Ann-Arbor, USA, pp. 139-145.

March, R.J., Baldessari, A., Gross, E., 1989. Determinacion de compuestos orgnicos en estructuras de combustion arqueologicas. In: Olive, M., Taborin, Y. (Eds.), Nature et Fonction des Foyers Préhistorique, Nemours, 1987. APRAIF, Nemours, France, pp. 47-58.

March, R.J., Lucquin, A., Joly, D., Ferreri, J.C., Muhieddine, M., 2014. Processes of formation and alteration of archaeological fire structures: complexity viewed in the light of experimental approaches. Journal of Archaeological Method and Theory 21, 1-45. doi:10.1007/s10816-012-9134-7

Marschner, B., Brodowski, S., Dreves, A., Gleixner, G., Gude, A., Grootes, P.M., Hamer, U., Heim, A., Jandl, G., Ji, R., Kaiser, K., Kalbitz, K., Kramer, C., Leinweber, P., Rethemeyer, J., Schäffer, A., Schmidt, M.W.I., Schwark, L., Wiesenberg, G.L.B., 2008. How relevant is recalcitrance for the stabilization of organic matter in soils? Journal of Plant Nutrition and Soil Science 171, 91-110. doi:10.1002/jpln.200700049

Mathe, C., Culioli, G., Archier, P., Vieillescazes, C., 2004. Characterization of archaeological frankincense by gas chromatography-mass spectrometry. Journal of Chromatography A 1023, 277-285. doi:10.1016/j.chroma.2003.10.016

Mentzer, S.M., 2012. Microarchaeological approaches to the identification and interpretation of combustion features in prehistoric archaeological sites. Journal of Archaeological Method and Theory 21, 616-668. doi:10.1007/s10816-012-9163-2 
Mills, J., 1966. The gas-chromatographic examination of paint media; Part I. Fatty acid composition and identification of dried oil film. Studies in Conservation 11, 92-106.

Nawar, W.W., 1969. Thermal decomposition of lipids - a review. Journal of Agricultural and Food Chemistry. 17, 18-21.

Nawar, W.W., 1989. Thermal decomposition of lipids An Overview, in: Parliment, T.H., McGorrin, R.J. and Ho, C.-T. (Eds.), Thermal Generation of Aromas. ACS Symposium Series, Washington DC, USA, pp. 94-104.

Nieuwenhuyse, O.P., Roffet-Salque, M., Evershed, R.P., Akkermans, P.M.M.G., Russell, A., 2015. Tracing pottery use and the emergence of secondary product exploitation through lipid residue analysis at Late Neolithic Tell Sabi Abyad (Syria). Journal of Archaeological Science. doi:10.1016/j.jas.2015.10.002

Pastorova, I., Botto, R.E., Arisz, P.W., Boon, J.J., 1994. Cellulose char structure: a combined analytical Py-GC-MS, FTIR, and NMR study. Carbohydrate Research 262, 27-47.

Perlès, C., 1977. Préhistoire du Feu. Masson, Paris, France.

Poirier, N., Sohi, S.P., Gaunt, J.L., Mahieu, N., Randall, E.W., Powlson, D.S., Evershed, R.P., 2005. The chemical composition of measurable soil organic matter pools. Organic Geochemistry 36, 1174-1189. doi:10.1016/j.orggeochem.2005.03.005

Pradeau, J., Salomon, H., Bon, F., Mensan, R., Lejay, M., 2014. Les matières colorantes sur le site aurignacien de plein air de Régismont-le-Haut ( Poilhes , Hérault ) Acquisition , transformations et utilisations. Bulletin de la Societé Préhistorique Française 111, 631-658.

Quenea, K., Derenne, S., Largeau, C., Rumpel, C., Mariotti, A., 2004. Variation in lipid relative abundance and composition among different particle size fractions of a forest soil. Organic Geochemistry 35, 1355-1370. doi:10.1016/j.orggeochem.2004.03.010

Quénéa, K., Derenne, S., Largeau, C., Rumpel, C., Mariotti, A., 2005. Spectroscopic and pyrolytic features and abundance of the macromolecular refractory fraction in a sandy acid forest soil (Landes de Gascogne, France). Organic Geochemistry 36, 349-362. doi:10.1016/j.orggeochem.2004.10.005

Quénéa, K., Mathieu, J., Derenne, S., 2012. Soil lipids from accelerated solvent extraction: Influence of temperature and solvent on extract composition. Organic Geochemistry 44, 45-52. doi:10.1016/j.orggeochem.2011.11.009 
Reber, E.A., Baumann, T.E., Monaghan, W.G., Myers, K.N., 2015. Absorbed residue analysis of a Mississippi Plain jar from Angel Mounds (12Vg1) lipid distribution revisited. Advances in Archaeological Practice 3, 29-49. doi:10.7183/2326-3768.3.1.29

Reber, E.A., Evershed, R.P., 2004. Identification of maize in absorbed organic residues: A cautionary tale. Journal of Archaeological Science 31, 399-410. doi:10.1016/j.jas.2003.09.008

Regert, M., 2011. Analytical Strategies for discriminating archeological fatty substances from animal origin. Mass Spectrometry Reviews 30, 177-220. doi:10.1002/mas

Regert, M., Alexandre, V., Thomas, N., Lattuati-Derieux, A., 2006. Molecular characterisation of birch bark tar by headspace solid-phase microextraction gas chromatography-mass spectrometry: a new way for identifying archaeological glues. Journal of Chromatography. A 1101, 245-53. doi:10.1016/j.chroma.2005.09.070

Roebroeks, W., Villa, P., 2011. On the earliest evidence for habitual use of fire in Europe. Proceedings of the National Academy of Sciences of the United States of America 108, 5209-14. doi:10.1073/pnas.1018116108

Rontani, J.-F., Aubert, C., 2008. Hydrogen and trimethylsilyl transfers during EI mass spectral fragmentation of hydroxycarboxylic and oxocarboxylic acid trimethylsilyl derivatives. Journal of the American Society for Mass Spectrometry 19, 66-75. doi:10.1016/j.jasms.2007.10.014

Rottländer, R.C.A., 1989. Chemische untersuchungen an sedimenten der Höhle Geissenklösterle bei Blaubeuren. Fundberichte Aus Baden-Württemberg 14, $23-32$.

Saiz-Jimenez, C., De Leeuw, J.W., 1986. Chemical characterization of soil organic matter fractions by analytical pyrolysis-gas chromatography-mass spectrometry. Journal of Analytical and Applied Pyrolysis 9, 99-119. doi:10.1016/0165-2370(86)85002-1

Sandgathe, D.M., Dibble, H.L., Goldberg, P., McPherron, S.P., Turq, A., Niven, L., Hodgkins, J., 2011. Timing of the appearance of habitual fire use. Proceedings of the National Academy of Sciences of the United States of America 108, E298; author reply E299. doi:10.1073/pnas.1106759108

Shadkami, F., Helleur, R., 2010. Recent applications in analytical thermochemolysis. Journal of Analytical and Applied Pyrolysis 89, 2-16. doi:10.1016/j.jaap.2010.05.007 
Simoneit, B.R.T., 2002. Biomass burning - A review of organic tracers for smoke from incomplete combustion. Applied Geochemistry 17, 129-162. doi:10.1016/S0883-2927(01)00061-0

Simoneit, B.R.T., 2005. A review of current applications of mass spectrometry for biomarker/molecular tracer elucidation. Mass Spectrometry Reviews 24, 719-65. doi:10.1002/mas.20036

Simoneit, B.R.T., Rogge, W.F., Mazurek, M.A., Standley, L.J., Hildemann, L.M., Cass, G.R., 1993. Lignin pyrolysis products, lignans, and resin acids as specific tracers of plant classes in emissions from biomass combustion. Environmental Science and Technology 27, 2533-2541. doi:10.1021/es00048a034

Spangenberg, J.E., Ferrer, M., Jacomet, S., Bleicher, N., Schibler, J., 2014. Molecular and isotopic characterization of lipids staining bone and antler tools in the Late Neolithic settlement, Zurich Opera Parking, Switzerland. Organic Geochemistry 69, 11-25. doi:10.1016/j.orggeochem.2014.01.015

Steele, V., 2013. Organic residues in archaeology: The highs and lows of recent research. In: Armitage, R.A. and Burton, J.H. (Eds.), Archaeological Chemistry VIII. ACS Symposium Series, Washington DC, USA, pp. 89-108. doi:10.1021/bk-2013-1147.ch005

Théry-Parisot, I., 2001. Economie des Combustibles au Paléolithique. CNRS, Paris.

Théry-Parisot, I., 2002. Fuel management (bone and wood) during the Lower Aurignacian in the Pataud Rock Shelter (Lower Palaeolithic, Les Eyzies de Tayac, Dordogne, France). Contribution of experimentation. Journal of Archaeological Science 29, 1415-1421. doi:10.1006/jasc.2001.0781

Théry-Parisot, I., Chabal, L., Costamagno, S., 2010. Taphonomie de la Combustion des Résidus Organiques et des Structures de Combustion en Contexte Archéologique. Actes de table ronde, 27-29 mai 2008, Valbonne. P@lethnologie, Toulouse, France.

Théry-Parisot, I., Costamagno, S., 2005. Propriétés combustibles des ossements : données expérimentales et réflexions archéologiques sur leur emploi dans les sites paléolithiques. Gallia Préhistoire 47, 235-254. doi:10.3406/galip.2005.2051

Van Den Berg, J.D.J., Van Den Berg, K.J., Boon, J.J., 2002. Identification of noncross-linked compounds in methanolic extracts of cured and aged linseed oilbased paint films using gas chromatography-mass spectrometry. Journal of 
843 Vilegas, J.H.Y., Lanças, F.M., Vilegas, W., Pozetti, G.L., 1997. Further triterpenes, steroids and furocoumarins from brazilian medicinal plants of Dorstenia genus ( Moraceae ). Journal of the Brazilian Chemical Society 8, 529-535. doi:10.1590/S0103-50531997000500016

Villa, P., Bon, F., Castel, J.-C., 2002. Fuel, fire and fireplaces in the palaeolithic of Western Europe. The Review of Archaeology 23, pp. 33-42.

Volkman, J.K., 2005. Sterols and other triterpenoids: source specificity and evolution of biosynthetic pathways. Organic Geochemistry 36, 139-159. doi:10.1016/j.orggeochem.2004.06.013

Wexler, H., 1964. Polymerization of drying oils. Chemical Reviews 64, 591-611. doi:10.1021/cr60232a001

Wiesenberg, G.L.B., Lehndorff, E., Schwark, L., 2009. Thermal degradation of rye and maize straw: Lipid pattern changes as a function of temperature. Organic Geochemistry 40, 167-174. doi:10.1016/j.orggeochem.2008.11.004

\section{Table 1}

Sample description, experimental parameters and organic carbon content (Corg) of upper subsamples (visually-identified as affected by the experiment) and of lower subsamples (visually unaffected by the experiment).

\begin{tabular}{|c|c|c|c|}
\hline Name & Subsample & Description & $\mathrm{C}_{\text {org }}$ \\
\hline Control & - & $\begin{array}{l}\text { Yellow sandy loam with frequent calcitic features (e.g. hypocoatings, } \\
\text { nodules) }\end{array}$ & $0.3 \%$ \\
\hline \multirow[t]{2}{*}{ Soil with bone OM } & Upper & $\begin{array}{l}\text { Yellow to brown sandy loam with frequent calcitic features and } \\
\text { organic fluids impregnation; } 2 \mathrm{~cm} \text { thick }\end{array}$ & $4.7 \%$ \\
\hline & Lower & Similar to control & $0.2 \%$ \\
\hline \multirow[t]{2}{*}{ Bone fire } & Upper & $\begin{array}{l}\text { Reddened and carbonized sandy loam with frequent calcitic features } \\
\text { and fine carbon coatings/infillings ; } 4 \mathrm{~cm} \text { thick }\end{array}$ & $2.3 \%$ \\
\hline & Lower & Similar to control & $0.3 \%$ \\
\hline \multirow[t]{2}{*}{ Wood+bone fire } & Upper & $\begin{array}{l}\text { Reddened and carbonized sandy loam with frequent calcitic features } \\
\text { and fine carbon coatings/infillings } ; 2.5 \mathrm{~cm} \text { thick }\end{array}$ & $0.9 \%$ \\
\hline & Lower & Similar to control & $0.3 \%$ \\
\hline \multirow[t]{2}{*}{ Wood fire } & Upper & $\begin{array}{l}\text { Reddened sandy loam with frequent calcitic features and rare } \\
\text { combustion residues on surface } ; 1.5 \mathrm{~cm} \text { thick }\end{array}$ & $0.2 \%$ \\
\hline & Lower & Similar to control & $0.2 \%$ \\
\hline
\end{tabular}




\section{Table 2}

Compounds in extract of the samples. The molecular weight (MW) and the main mass fragments of TMS derivatives are reported (with decreasing contributions). Compound numbers are reported in Fig. 2. The same peak number may correspond to several co-eluting compounds.

\begin{tabular}{llll}
\hline Peak \# & Main fragments $(m / z)$ & MW & Name \\
\hline 1 & $179,105,77,135,194$ & 194 & Benzoic acid, TMS \\
2 & $73,147,205,293$ & 308 & Glycerol, TMS \\
3 & $193,119149,91,208$ & 208 & 2-Methylbenzoic acid, TMS \\
4 & $151,73,210,195,117,167$ & 210 & 2-Phenoxy-ethanol, TMS \\
5 & $71,89,56,43,173,143$ & 216 & Propanoic acid, 2-methyl-, 2-ethyl-3-hydroxyhexyl ester \\
6 & $43,71,145,83,161,98$ & 304 & 1,3-Diisobutyrin, TMS \\
7 & $227,75,143,129$ & 242 & 3-Methyldecen-1-ol, TMS \\
8 & $194,193,73,209,224$ & 224 & Vanillin, TMS \\
9 & $57,71,83$ & 242 & Octyl ether \\
& 257 & 257 & Dimethylbenzoacridine \\
10 & $195,210,180,165$ & 210 & Naphthalene, 1,2,3-trimethyl-4-propenyl-, (E)- \\
11 & $195,119,73,103$ & 252 & 2 -Acetoxy-benzoic acid (TMS) \\
12 & $88,101,157,284,239$ & 284 & Hexadecanoic acid, ethyl ester \\
13 & $85,236,192,97$ & 254 & Y-Palmitolactone \\
14 & $85,97,220,264$ & 282 & Y-Stearolactone \\
15 & $343,73,147,227,431,371,205$ & 446 & 1 -Monomyristin, TMS \\
16 & $317,73,215,147$ & 532 & $10, \omega$-Dihydroxy-octadecanoic acid, TMS \\
17 & $129,218,73,147,103,313,459,403$ & 474 & 2-Monopalmitin, TMS \\
18 & $369,73,129,147,55,370,457$ & 472 & 1 -Monopalmitolein, TMS \\
19 & $371,73,147,459$ & 474 & 1-Monopalmitin, TMS \\
20 & $103,129,73,218,147$ & 500 & 2-Monoolein, TMS \\
21 & $129,218,147,341,103,487$ & 502 & 2-Monostearin, TMS \\
22 & $397,73,129,147,103$ & 500 & 1 -Monoolein, TMS \\
23 & $399,73,147,129,267,487$ & 502 & 1 -Monostearin, TMS \\
24 & $69,81,137,95,121$ & 410 & Squalene \\
25 & $329,129,368,458$ & 458 & Cholesterol, TMS \\
26 & $83,129,484,394,255$ & 484 & Stigmasterol, TMS \\
27 & $204,300,133,285,424$ & 424 & Taraxerone \\
28 & $129,357,396,486,255$ & 486 & Sitosterol, TMS \\
29 & $218,424,203$ & 424 & a-Amyrone \\
30 & $424,205,189,409$ & 424 & Lupenone \\
31 & $129,145,313,329,385,625$ & 640 & 1 -2-Dipalmitin, TMS \\
32 & $371,372,73,385,625$ & 640 & 1,3 -Dipalmitin, TMS \\
\hline & & & \\
& & &
\end{tabular}




\section{Table 3}

Compounds from py(TMAH)-GC-MS analysis of bulk OM. The MW and main mass fragments of original compounds or methylated derivatives are reported (with decreasing contribution). Peak numbers are reported in Fig. 3. The same peak number may correspond to several coeluting compounds.

\begin{tabular}{llll}
\hline Peak \# & Main mass fragments $(m / z)$ & MW & Name \\
\hline 1 & $45,75,88,102$ & 120 & 1,3 -Dimethoxy-2-propanol \\
2 & $59,45,89,102$ & 134 & $1,2,3$-Trimethoxypropane \\
3 & $55,41,68,84,112$ & 112 & Cycloheptanone \\
4 & $41,57,70,82,98,114,124$ & 142 & Nonanal \\
5 & $119,134,91,115$ & 134 & $1,2,3,5$-Tetramethylbenzene \\
6 & $119,134,91,77,65$ & 134 & $1,2,4,5$-Tetramethylbenzene \\
7 & $133,148,105,91,115$ & 148 & Pentamethylbenzene \\
8 & $147,162,91,119,105,77$ & 162 & $1,2,4$-Trimethyl-5-(1-methylethyl)benzene \\
9 & $147,162,133,91,105$ & 162 & 1,2 -Diethyl-3,4-dimethylbenzene \\
10 & $147,162,91,105,119,131$ & 162 & Hexamethylbenzene \\
11 & 101,88 & 298 & Heptadecanoic acid, ethyl ester \\
12 & $71,18395,294$ & 326 & 8-Methoxy-9-octadecenoic acid, methyl ester \\
13 & $71,227,163,81,294$ & 340 & 12,13-Epoxy-11-methoxy-9-octadecanoic acid, methyl ester \\
14 & $71,213,169,294$ & 326 & 10-Methoxy-8-octadecenoic acid, methyl ester \\
& $71,169,227,294$ & 326 & 9 -Methoxy-10-octadecenoic acid, methyl ester \\
15 & $131,71,241$ & 328 & 4-Methoxy-octadecanoic acid, methyl ester \\
& $83,145,201$ & 302 & 6,10-Dihydroxyhexadecanoic acid, methyl ester \\
& 229,143 & 328 & 11-Methoxy-octadecanoic acid, methyl ester \\
16 & $55,74,155$ & 330 & 9,10 -Dihydroxyoctadecanoic acid, methyl ester \\
17 & $69,201,83,137$, & 358 & 9,18-Dimethoxyoctadecenoic acid, methyl ester \\
\hline
\end{tabular}




\section{Table 4}

Summary of specific components in the extracts (GC-MS) and in the bulk soil OM composition [py(TMAH)-GC-MS], and possible origins. In grey, compounds with an expected long-term preservation due to their recalcitrance (according to literature, see §3.4).

\begin{tabular}{|c|c|c|c|c|c|c|c|}
\hline & & Control & $\begin{array}{l}\text { Soil with } \\
\text { bone OM }\end{array}$ & Bone fire & $\begin{array}{l}\text { Wood + bone } \\
\text { fire }\end{array}$ & Wood fire & Possible origin \\
\hline \multirow{16}{*}{ 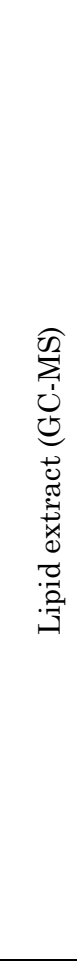 } & Saturated $n$-acids $>\mathrm{C}_{18}$ & $\mathrm{X}$ & & & $\mathrm{X}$ & $\mathrm{X}$ & Plant OM \\
\hline & $n$-Alcohols $>\mathrm{C}_{17}$ & $\mathrm{X}$ & & & & $\mathrm{X}$ & Plant OM \\
\hline & $n$-Alkanes & $\mathrm{X}$ & & & & $\mathrm{X}$ & Plant OM \\
\hline & Phytosterols & $\mathrm{X}$ & & & & $\mathrm{X}$ & Plant OM \\
\hline & Terpenes & $\mathrm{X}$ & & & & & Plant OM \\
\hline & Benzoic acids & & & & $\mathrm{X}$ & $\mathrm{X}$ & Plant OM \\
\hline & Phenolic compounds & & & & & $\mathrm{X}$ & Plant OM \\
\hline & Other aromatic compounds & & & & & $\mathrm{X}$ & $\begin{array}{l}\text { Thermal alteration } \\
\text { of plant OM }\end{array}$ \\
\hline & Diacids & & $\mathrm{X}$ & $\mathrm{X}$ & $\mathrm{X}$ & & Animal fat \\
\hline & (di)Hydroxyacids & & $\mathrm{X}$ & & & & Animal fat \\
\hline & $\begin{array}{l}\text { Monomethyl branched } \\
\text { dicacids }<\mathrm{C}_{10}\end{array}$ & & & $\mathrm{X}$ & & & $\begin{array}{l}\text { Slight thermal } \\
\text { alteration of animal } \\
\text { fat }\end{array}$ \\
\hline & Oxoacids & & & $\mathrm{X}$ & $\mathrm{X}$ & & $\begin{array}{l}\text { Thermal alteration } \\
\text { of animal fat }\end{array}$ \\
\hline & $\begin{array}{l}\text { Monomethyl branched } \\
\text { acids }<\text { Me-C12 }\end{array}$ & & & $\mathrm{X}$ & $\mathrm{X}$ & & $\begin{array}{l}\text { Thermal alteration } \\
\text { of animal fat }\end{array}$ \\
\hline & $n$-Alcohols $<\mathrm{C}_{17}$ & & & $\mathrm{X}$ & $\mathrm{X}$ & & $\begin{array}{l}\text { Thermal alteration } \\
\text { of animal fat }\end{array}$ \\
\hline & Ketones & & & $\mathrm{X}$ & $\mathrm{X}$ & & $\begin{array}{l}\text { Thermal alteration } \\
\text { of animal fat }\end{array}$ \\
\hline & Lactones & & & $\mathrm{X}$ & $\mathrm{X}$ & & $\begin{array}{l}\text { Thermal alteration } \\
\text { of animal fat }\end{array}$ \\
\hline \multirow{6}{*}{ 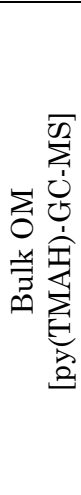 } & Benzene derivatives & & & & $\mathrm{X}$ & $\mathrm{X}$ & $\begin{array}{l}\text { Thermal alteration } \\
\text { of plant OM }\end{array}$ \\
\hline & $\begin{array}{l}\text { Monomethyl branched } \\
\text { unsaturated } \mathrm{C}_{9} \text { and } \mathrm{C}_{10} \\
\text { acids, high } \mathrm{C}_{8} \text { and } \mathrm{C}_{9} \\
\text { saturated } n \text {-acids }\end{array}$ & & $\mathrm{X}$ & & & & Animal fat \\
\hline & Diacids & & $\mathrm{X}$ & $\mathrm{X}$ & & & Animal fat \\
\hline & $\begin{array}{l}\text { (di)Hydroxy-, epoxy- } \\
\text { saturated and unsaturated } \\
\text { acids }\end{array}$ & & $\mathrm{X}$ & $\mathrm{X}$ & & & Animal fat \\
\hline & Glycerol derivatives & & $\mathrm{X}$ & $\mathrm{X}$ & & & Animal fat \\
\hline & $\begin{array}{l}n \text {-Alkane/ } n \text {-alkene } \\
\text { doublets }\end{array}$ & & & $\mathrm{X}$ & $\mathrm{X}$ & & $\begin{array}{l}\text { Thermal alteration } \\
\text { of animal fat }\end{array}$ \\
\hline
\end{tabular}


List of figures:

865 Fig. 1. Pictures of Regismont-le-Haut (France) experimental structures during 866 summer 2012 experimental session; (a) section of an experimental fireplace with 867 the localization of upper and lower subsamples, (b) Soil with bone OM 868 experiment after removal of bone fragments, (c) Bone fire experiment after 869 removal of combustion residues, (d) Bone+wood fire experiment after removal of 870 combustion residues, (e) Wood fire experiment after removal of combustion 871 residues. The scale is $10 \mathrm{~cm}$ long in (a), $24 \mathrm{~cm}$ long in (b), (c), (d) and (e).

872 Fig. 2. Total ion Chromatogram (TIC) of silylated extract of the (a) Control, (b) 873 Soil with bone OM, (c) Bone fire, (d) Wood+bone fire and (e) Wood fire. Numbers 874 refer to Table 2; p, plastic derivative; c, column peak. $\mathrm{C}_{\mathrm{x}}$ indicates number of 875 carbons in the linear chain.

876 Fig. 3. TIC trace from py(TMAH)-GC-MS analysis for (a) Soil with bone OM, (b) 877 Bone fire, (c) Wood+bone fire and (d) Wood fire. Numbers refer to Table 3. $\mathrm{C}_{\mathrm{x}}$ 878 indicates number of carbons in the linear chain. 

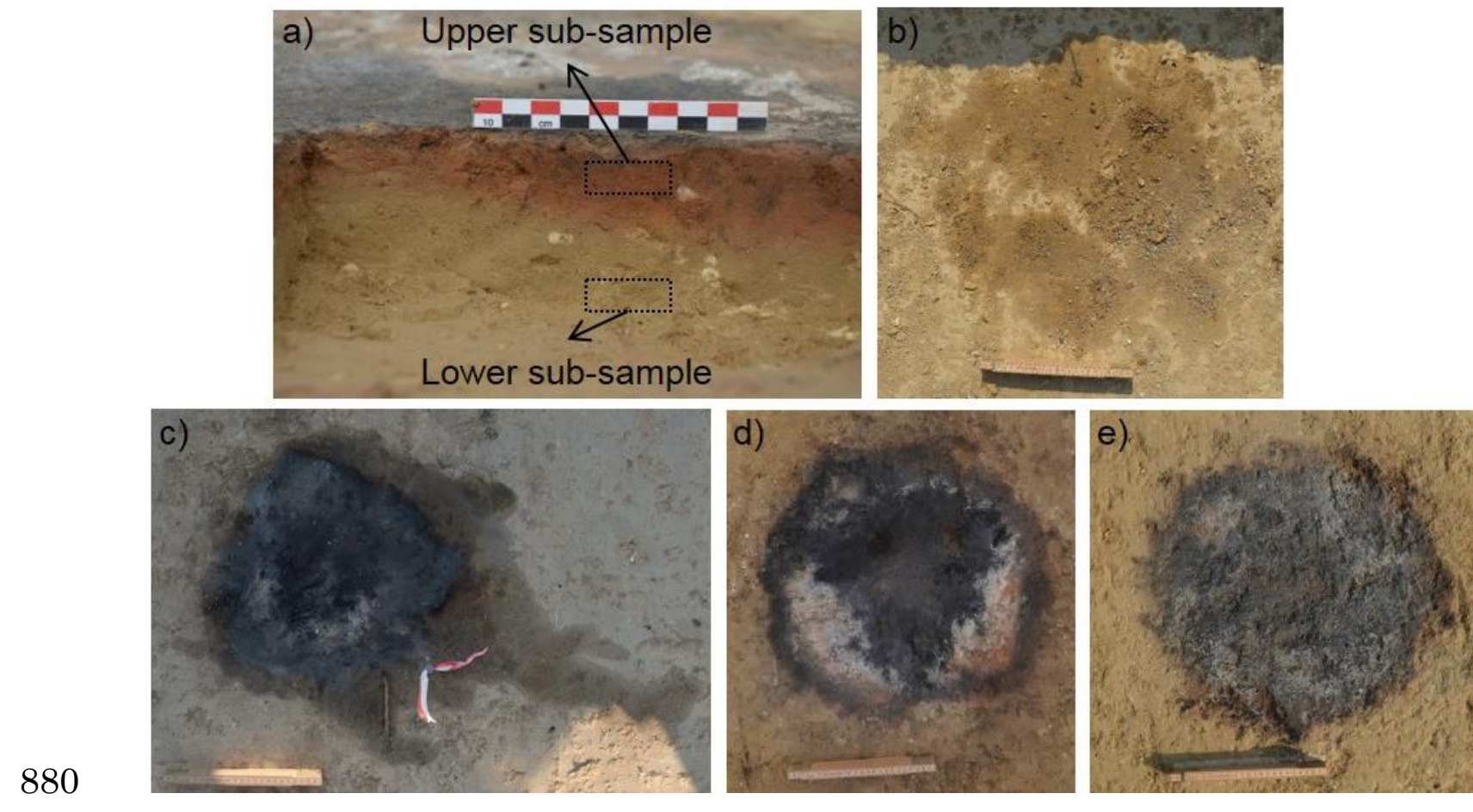

881 
a)

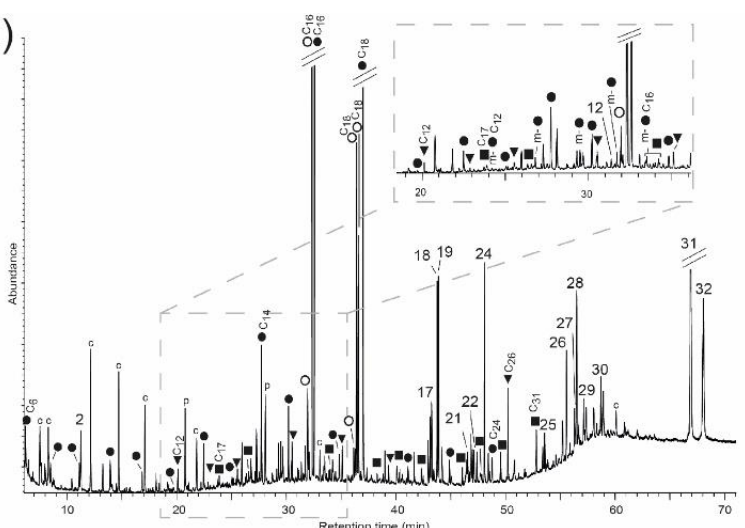

b)

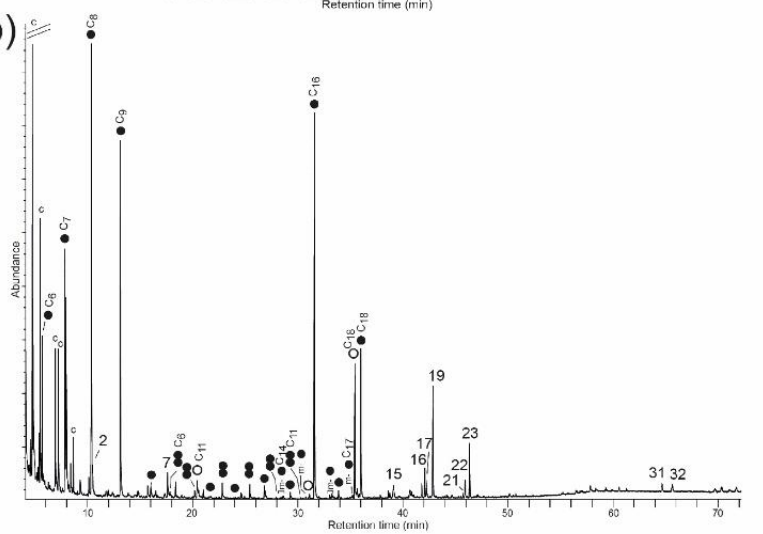

- Saturated n-acids

- Unsaturated n-acids

- Diacids

m- Monomethyl branched

ox- Oxo-

$\checkmark$ n-Alcohols

- n-Alkanes

< Ketones c)

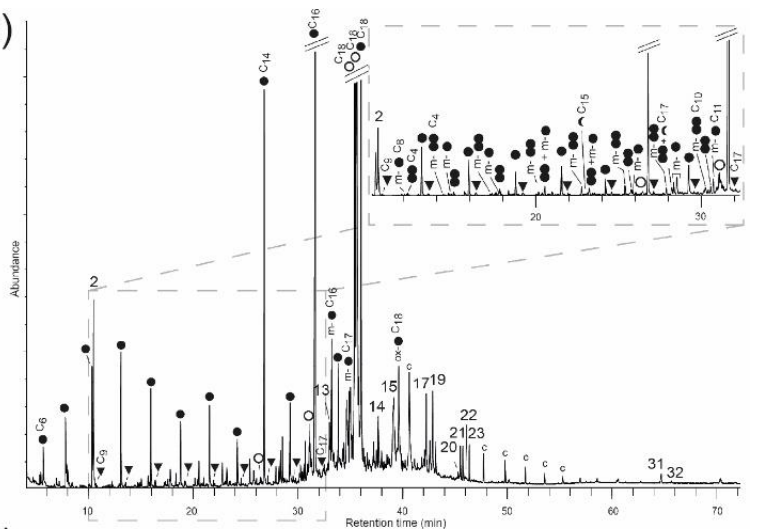

d)

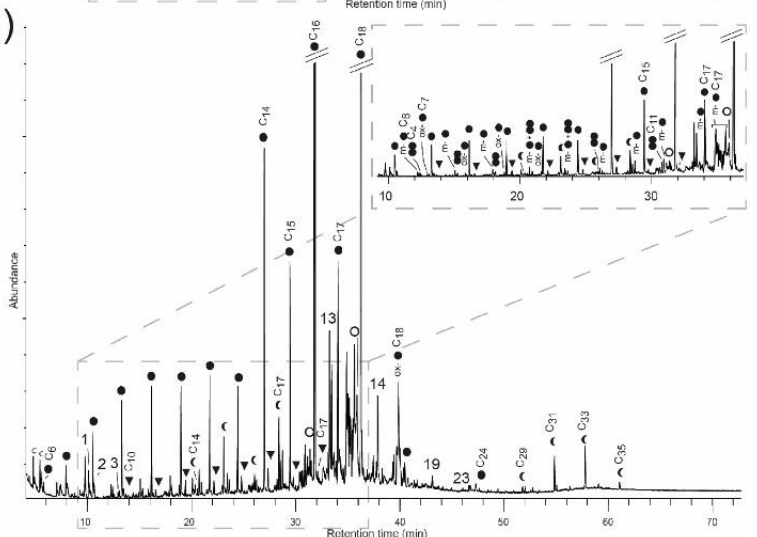

e)

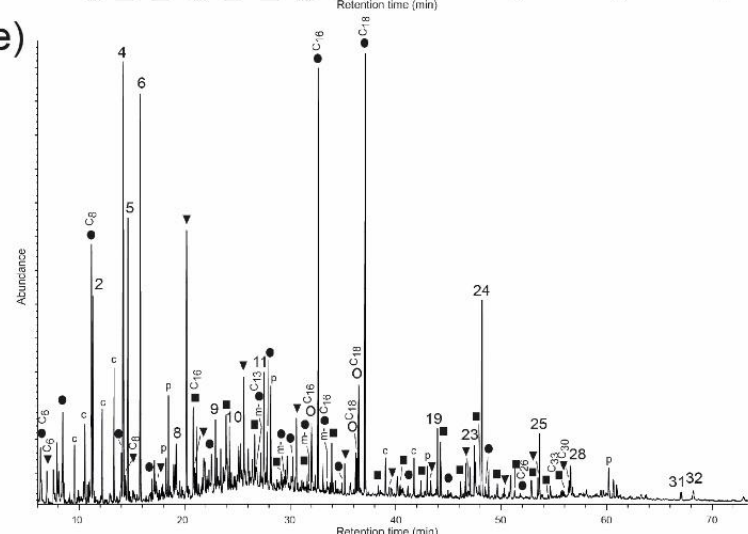

882 
a)

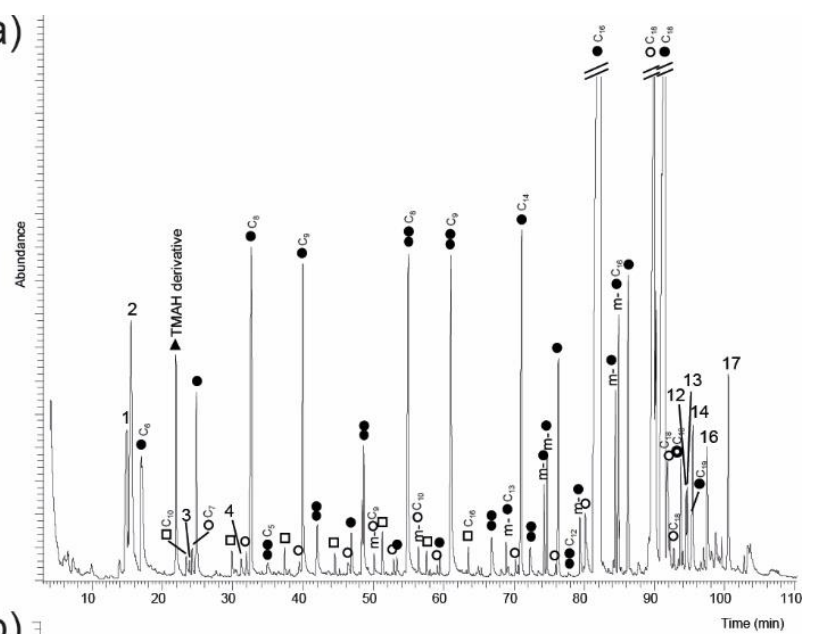

b)

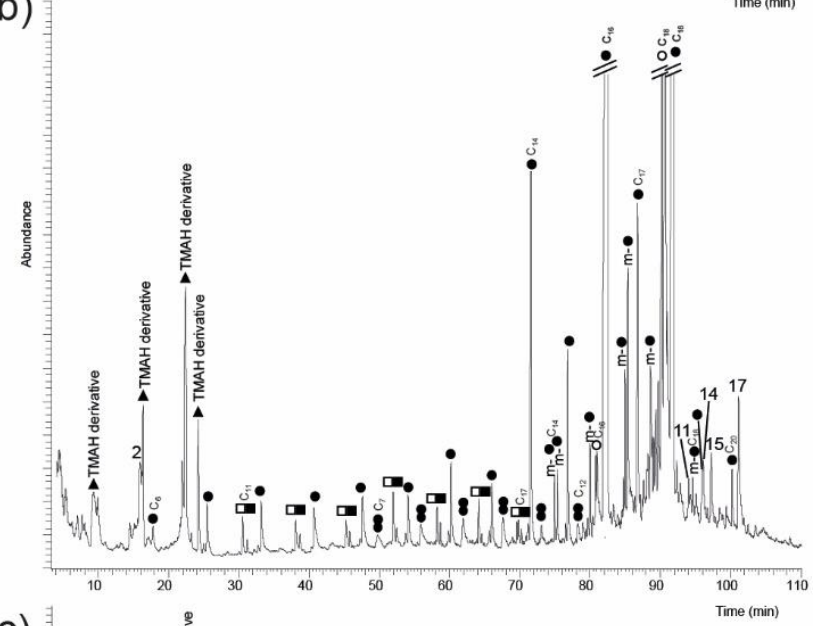

c)

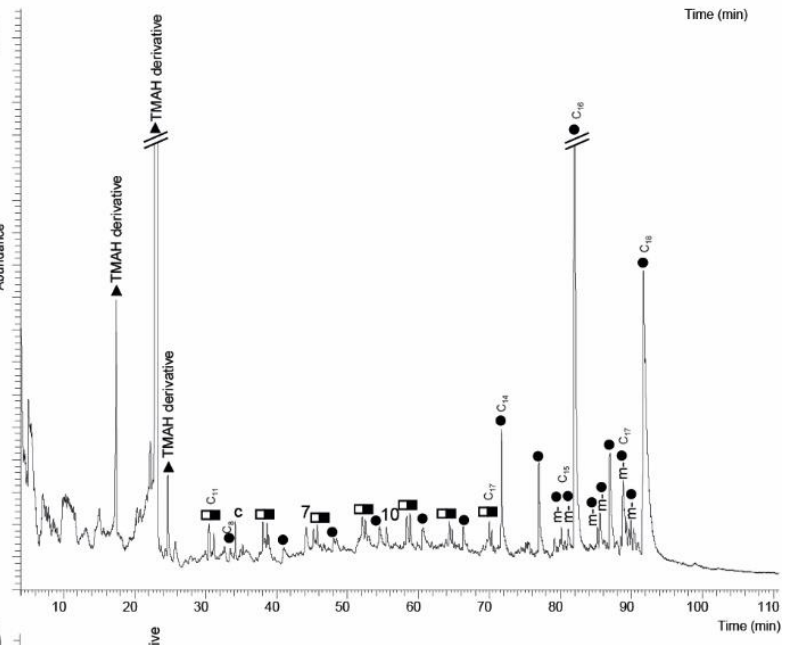

d)

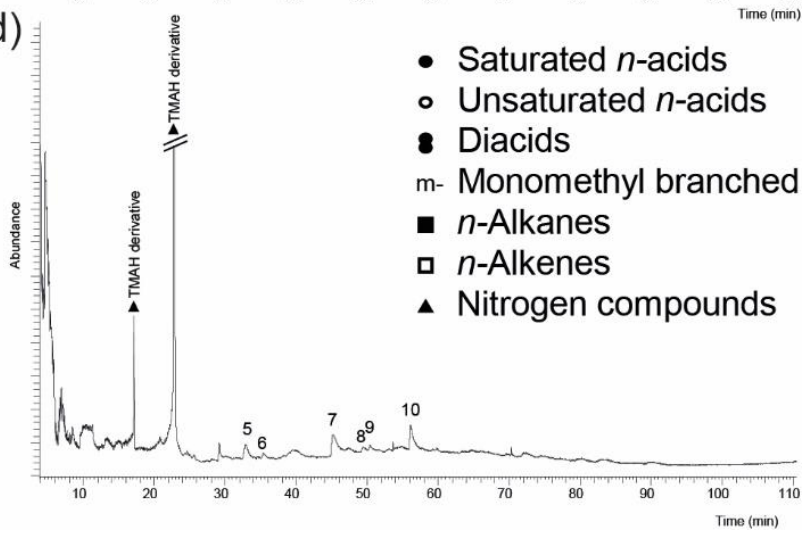

